\title{
Bude literární věda exaktní vědou ve století jednadvacátém?
}

\author{
Richard Změlík
}

\section{ABSTRACT}

Will Literary Studies be an Exact Science in the Twenty First Century?

The study deals with the possibilities of implementing the so called exact methods in literary studies. In the first parth of the text we observed the tradition of using quantitative methods in the context of literary studies. We deal with chosen methods of this methodological approach. In the second parth, we touch upon the issues with methods in literary studies. We claim, this usage a special literary corpus can be useful for literary praxis, but the using must include interpretation as the most important and irreplacable part of a complex literary analysis.

\section{KEYWORDS}

Exact methods in the literary studies, quantitative approach in literary studies, literary corpus, quantitative analysis and interpretation.

\section{KLÍčOVÁ SLOVA}

Exaktní metody v literární vědě, kvantitativní přístup v literární vědě, literární korpus, kvantitativní analýza a interpretace.

Jestliže název tohoto příspěvku je parafrází známé studie Jiřího Levého Bude literární věda exaktní vědou?, potom jeho smyslem nemá být pouze opakování Levého teoretických tezí směřujících $\mathrm{k}$ požadavku exaktnosti v literární vědě, ale především kritická reflexe dvou klíčových pojmů - literární věda a exaktnost, které nejednou vyvolaly nedorozumění, dokonce kontroverze. Položme si na úvod otázku, zda jsme vůbec oprávněni literární vědu nazývat vědou, není-li v pravém slova smyslu vědou exaktní? A není-li literární věda exaktní vědou, může takovou někdy být? A měla by jí být? Kladením takovýchto otázek se 
dostáváme do oblasti nelehkých a nejednoznačných úvah, jejichž společným jmenovatelem se stává pojem vědeckosti.

$\mathrm{Z}$ dobře známých důvodů, které $\mathrm{v}$ tuto chvíli není potřeba podrobněji rozvádět, můžeme základní předpoklad vědeckosti definovat následovně: Věda je takovým způsobem vztahu subjektu ke světu jevů, který jako svůj fundament využívá základních principů racionality a logiky a který pro potřeby poznávání těchto jevů vypracovává koherentní soubory pracovních postupů. Jinými slovy, každá z vědeckých disciplín je vedle této výchozí epistemologické platformy určena povahou zkoumaného jevu a k němu účelově vypracovanými metodami zkoumání. Předmětem vědeckého zájmu potom může být jakýkoli jev, at již ze světa přírodního nebo kulturního. Byly to ovšem přírodní vědy, které sehrály důležitou úlohu v pojetí takového způsobu poznání, které v jeho intencích označujeme za vědecké a též exaktní. Vzhledem k povaze zkoumaných jevů mají $\mathrm{v}$ přírodních vědách podstatnou úlohu empirické metody, s nimiž je nejčastěji spojován pojem exaktnost.

V průběhu 19. století došlo ke snaze fundovat rovněž humanitní a společenskovědní disciplíny na tímto zpưsobem osvojených principech vědeckosti. V literární vědě je toto období spojeno s pracemi pozitivistů, kteří směřovali k vysvětlení literatury jako výslednice psychologických procesů, které jsou samy o sobě determinovány procesy biologickými. Literatura byla ve skutečnosti chápána jako důsledek vývojového stádia určitého národa, jeho rasy, temperamentu, vlivu prostředí apod. V literatuře se v zásadě měly manifestovat evoluční symptomy dané society, národa. Proto i zkoumání literárních děl mělo in principio vycházet $\mathrm{z}$ metodologického rámce, který se uplatnil v přírodních vědách, zejména biologii. Důraz na exaktní přístup reprezentovaný prrírodovědnými metodami však s sebou zejména od počátku 20. století přinesl i jeho systematickou kritiku. Jejím společným tématem se staly výtky proti přiliš redukcionistickému pojetí literatury. Kritici pozitivistické metody (ruští formalisté, strukturalisté ad.) zdůrazňovali nutnost soustředit se na literární dílo jako takové a nesměšovat je s kvalitativně zcela odlišnými jevy, zejména s psychologií či sociologií, anebo tak alespoň nečinit bezprostředně kauzálně. Postupné vymezování se proti pozitivismu znamenalo důležitý krok na cestě k metodologické autonomizaci moderní literární vědy. Na jejím počátku se objevují podobné principy, jaké bychom mohli najít u základů každé vědecké disciplíny. Kritické myšlení o literatuře si postupně zformulovalo výchozí předmět zkoumání a k němu vypracovalo soubory vlastních metodologických kritérií, které měly za úkol respektovat tento předmět $\mathrm{v}$ jeho jedinečné povaze a kvalitě. To umožnilo konstituovat literární 
vědu jakožto samostatnou disciplínu. Uvedený krok ovšem pro literární vědu neznamená její izolaci od ostatních disciplín. Od počátku 20. století a stejně tak i v jeho průběhu se literární věda a její teorie spolu s metodologií vyvijí v poměru k jiným disciplínám, mezi kterými mají své důležité místo i exaktní vědy (např. formalismus, strukturalismus, aktuálně Digital Literary Studies).

Důležitý podíl na svébytnosti literární vědy měla a má i její metakritika. Je proto přirozené, že se v jejím kontextu (zejména ve 20. století) objevují mnohdy značně protikladné názory na povahu a úkoly literární vědy. Na základní rozpor v pojetí literární vědy jako na jedné straně vědecké, tj. pojmové disciplíny, na straně druhé v zásadě disciplíny nevědecké upozornil i René Wellek v jedné ze svých stěžejních prací: „Někteří teoretikové by prostě nepřipustili, že zkoumání literatury přináší poznání, a doporučili by ,sekundární tvorbu', jejíž výsledky dnes většině z nás připadají chabé. [...] Takováto ,tvưrčí kritika' byla obvykle pouhým nepotřebným zdvojením nebo přinejlepším překladem jednoho uměleckého díla do jiného, obvykle horšího. Jiní teoretikové vyvozují z našeho rozlišení mezi literaturou a jejím zkoumáním ${ }^{1}$ jiné, spíše skeptické závěry: tvrdí, že literaturu nelze ,zkoumat' vůbec. Můžeme ji pouze číst, těšit se jí, hodnotit ji. Co se ostatního týče, můžeme pouze shromažd’ovat různé druhy informací ,o' literatuře. [...] V praxi se to projevuje $v$ důrazu na vnější ,fakta' a v přezíravém postoji ke všem pokusům jít za ně“ (WELLEK 1996: 17-18). Ačkoli Wellek odmítá nekritický přístup v literární vědě, skepticky se staví také vưči exaktním metodám: „Jinou aplikací je snaha napodobovat přírodovědecké metody zkoumání přičinných souvislostí; v praxi tato ,genetická metoda' ospravedlňuje sledování jakéhokoli vztahu, pokud to chronologie umožňuje. Přísněji aplikovaná vědecká kauzalita obvykle vysvětluje literární jevy tak, že za determinující příčiny označí ekonomické, sociální a politické podmínky“ (WELLEK 1996: 18-19). Wellek, jenž byl před válkou členem Pražského lingvistického krouž$\mathrm{ku}, \mathrm{z}$ pochopitelných důvodů odmítá pozitivismus a spolu s ním i některé jím aplikované exaktní metody. Jak píše dále, „[i] zde jsou zaváděny kvantitativní metody, které jsou vhodně využivány v jiných vědeckých oborech, tj. statistiky, tabulky a grafy. [...] Přírodovědecké metody prokázaly svoji hodnotu v rámci přísně vymezené oblasti nebo za pomoci zúžené techniky, jako je použití statistiky u určitých metod textologie nebo při zkoumání metriky. Většina propagátorů této přírodovědecké invaze do zkoumání literatury však bud’ přiznala neúspěch a dospěla ke skepsi, nebo nalezla útěchu v iluzích, že by ona vědecká

1) „[N]ejprve musíme odlišit literaturu od zkoumání literatur. Jedná se o dvě různé činnosti: jedna je tvůrčí, umělecká, zatímco druhá, i když není přísně vzato vědou, je jistým druhem poznání, nauky“ (WELLEK 1996: 17). 
metoda mohla přinést úspěch v budoucnosti“ (WELLEK 1996: 19). Uvedená polarita, kdy na jedné straně stojí snaha přibližit literární vědu disciplínám, které ve svém základě disponují exaktními metodami, na straně druhé naopak úsilí v maximální míře respektovat jedinečnou povahu literárního jevu a jeho kontextu, je jednou (nikoli jedinou) z podstatných sil, které stojí v základech proměňujícího se diskurzu literární teorie i literárněvědné metodologie ve 20. století. Obě tendence jsou důležité, nebot’ se spolupodílí na definování literární vědy jakožto autonomní vědecké disciplíny.

Jednou z oblastí, kde se tato oscilace projevuje, je samotné vymezení výchozích literárněvědných disciplín. Tradiční pojetí literární vědou rozumí literární teorii, literární historii a literární kritiku (viz WELLEK 1996: 52-63). Na problematičnost, která vyplývá ze zapojení literární kritiky do literární vědy, upozornil Jiří Levý, pro kterého literární kritika není v pravém slova smyslu vědeckou disciplínou: „Celá řada literárněvědných metodologií - počínaje pozitivismem - byla motivována úsilím vybudovat exaktní teorii literatury. Předpokladem každé úvahy na toto téma je vyjasnění poměru mezi literární vědou a literární kritikou. Podstatou věci je zde různě chápané kritérion pravdivosti výroků v obou disciplínách. [...] [Li]terární kritika je umění, a jako v umění tak i v kritickém eseji jednotlivá tvrzení mají platnost ,pseudovýrokư a není podstatná otázka jejich ,doslovné pravdivosti. [...] Pokud ovšem literární věda chce být vědou, pak celý soubor jejích výroků má za cíl pravdivost; z logického hlediska jde o (teoretický) jazykový popis (uměleckého) jazykového sdělení, tedy o tzv. metajazyk" (LEVÝ 1971: 9, 10). ${ }^{2}$

Levého úsilí v literární teorii bylo motivováno snahou opět přiblí̌it literární vědu dobovému ideálu exaktních věd, což ovšem znamenalo využít poznatků teorie informace a kybernetiky. Levý pak literární vědě nabízí zajímavý teoretický rámec, ve kterém uplatňuje poznatky z obou disciplín. Z epistemologického hlediska je však důležité, že tyto disciplíny nepodmiňují literární vědu tak, jako tomu bylo v případě pozitivismu. Literární věda se nemá stát literárněvědnou teorií informace nebo literárněvědnou kybernetikou. Exaktní metody, které jsou matematické povahy, mají přinést literární vědě nové impulzy a podněty. Jinými slovy, jestliže pozitivismus směřoval ke konsolidaci literární vědy pod metodologickou egidou věd přírodních, Levý zdůrazňuje funkční implementaci metodologických poznatků teorie informace a kybernetiky do úkolů, jimiž se

2) Je ovšem nutné odlišit pojetí literární kritiky u Welleka a Levého. Wellek označením „kritika“ myslí spíše samotné kritické souzení, které se neobejde bez znalostí literární historie a teorie, zatímco u Levého je literární kritika žánrem konotovaným se subjektivním soudem vkusu. 
primárně zabývá literární věda; jedná se o otázky geneze, recepce nebo překladu literárního díla, vztahu formálních a významových prvků, ale také o vztah literárního díla a kontextu. Smyslem matematických metod aplikovaných v literární vědě je směřování $\mathrm{k}$ výzkumným otázkám literárněvědným, nikoli matematickým.

Rozvoj teorie informace a kybernetiky s sebou přinesl také důraz na kvantitativní aspekty, jejichž využití můžeme od druhé poloviny 20. století sledovat především v lingvistice, kde kvantitativní metody nalezly významné uplatnění. V českém prostředí náleží $\mathrm{k}$ nejpodnětnějším práce Marie Těšitelové (viz TĚŠITELOVÁ 1974, 1987), která při sledování obecné problematiky lexikonu materiálově čerpala také z beletrie. Ačkoli její bádání primárně směřuje do oblasti lingvistiky, kvantitativní analýza uměleckých textů se zdála nabízet jistý potenciál také pro literárněvědnou reflexi. Na poznatky Těšitelové se proto snažil navázat Miroslav Klivar ve studii Význam kvantitativní lingvistiky pro literární teorii (1984). Autorovi se však prakticky nepodařilo překročit hranice, které vytyčila Marie Těšitelová, takže s výjimkou úvodních velmi obecných konstatování de facto opakuje autorčiny poznatky a závěry.

Zcela jiná je situace v pracích Lubomíra Doležela z druhé poloviny 60. let. V roce 1969 Doležel společně s Richardem W. Baileyem uspořádali sborník studií Statistics and Style, který reflektuje problematiku kvantifikace umělecké literatury z pohledu, který již nutně nemusí být výhradně lingvistický. Doležel ve své studii hovoří o využití statistiky (konkrétně pravděpodobnosti) pro určení těch rysů textu, které jej dokáží statisticky identifikovat vzhledem ke konkrétní stylově příznakové textové množině. ${ }^{3}$ Pro přístup, který reprezentuje Doležel, je důležité zejména to, že je zde teorie a praxe statistiky využita nikoli ilustrativně, jak je tomu třebas ještě v některých pracích Jana Mukařovského, ale že tyto závěry jsou schopny aktivně ovlivňovat výzkum textu a jeho stylu. ${ }^{4}$

3) „Each text can be represented by a set of measurable, statistical characteristics: $T=\left\{C_{1}, C_{2} \ldots C_{2}\right\}$, in which $C_{i}$ symbolizes text characteristics. In other words, each text can be described in a multidimensional space, with the values of $C_{i}$ representing individual vectors. [...] A probabilistic approach reveals the stylistic stability (i.e., the stable probability distribution) behind the variability of concrete manifestations (i.e., the fluctuations of frequency distributions). By using specific statistical procedures - tests - the student of style is able to distinguish between insignificant fluctuations which do not affect the basic character of a style and significant fluctuations which signal differences in styles or stylistic change" (DOLEŽEL 1969: 17, 11). Takovými měřitelnými jednotkami jsou kupř́íladu slovní bohatství, průměrná délka vět nebo různé vztahy mezi komponenty textu, např. délkou slov a vět apod. (viz DOLEŽEL 1969: 19).

4) Ilustrativní používání statistiky Doležel připisoval předválečnému strukturalismu: „Pražská teorie básnického jazyka byla již charakterizována jako teorie statistické povahy. Ačkoli tato charakteristika je v podstatě správná, přece nelze zapomínat, že v pražských pracích nalézáme rovněž velmi cenné analýzy kvalitativně strukturních vztahů v básnickém textu. [...] Na druhé straně musím zdůraznit, že pražská teorie básnického jazyka má charakter prestatistický, protože zde nebyl aplikován ani ve vymezení, ani v analýze básnického jazyka skutečný aparát 
K otázkám kvantitativního zkoumání textu se Doležel vyjadřuje také v 80 . letech, kdy v rámci 51 . Nobelova sympozia ${ }^{5}$ reaguje na text profesora Alvara Ellegårda Genre styl, individual styles, and autorship identification (1982). ${ }^{6}$ Doleželova reakce signalizuje důležitý posun v uvažování o možnostech využití exaktních metod jak v lingvistice, tak potenciálně v literární vědě. Za zásadní lze pokládat nejen autorovo upozornění na možné omyly plynoucí z nekritické aplikace kvantitativních postupů při textové analýze, ale především nezbytnost relevantní interpretace výsledků vyplývajících z kvantitativní analýzy a statistického modelování: „We can master and use the most sophisticated statistical and probabilistic techniques, but this fancy equipment will continue to yield dubious results if the epistemological goals and theoretical foundations of quantitative text theory remain vague or primitive. It is especially imperative to clarify the relationship between qualitative statements and quantitative statements about textual phenomena. To put this task in operational terms, we have to develop carefully controlled procedure for moving from qualitative to quantitative text descriptions and vice versa. In the short time which is alloted to me I cannot do more than to outline briefly the problems connected with two such strategies (both of which are generally known in quantitative investigations), namely SCALING and INTERPRETATION. The first procedure can be characterized as transformation of qualitative properties into quantitative data, while the second one is conversion of numerical data into structural description [kurziva R.Z.]. These two strategies are indispensable for any empirical theory; the neglect of their foundations in the text study is, in my option, a major cause of our difficulties, misconceptions and misunderstanding“"(DOLEŽEL 1982: 540-541).

matematické statistiky. Hlavní věty teorie jsou statistické svým obsahem, nikoli svou formulací“ (DOLEŽEL, 1965: 103-104).

5) První Nobelovo sympozium se konalo v roce 1965 a zatím poslední, v pořadí 163., v roce 2017 (Seznam Nobelových sympozií: https://www.nobelprize.org/nobel_organizations/nobelfoundation/symposia/complete-list.html). Doležel v Doslovu překladatele knihy Možné světy v humanitních vědách, v umění a v přírodních vědách (2012) vzpomíná na 51. sympozium, na jehož závěru inicioval téma 65. ročníku, které se konalo v roce 1986 ve Švédsku pod názvem Possible Worlds in Arts and Sciences. Doležel ve zmíněném doslovu českého překladu mylně uvedl, že pro 51. ročník posuzoval studii Hanse Karlgrena věnovanou „statistické analýze textů a atribuci autorství“ (DOLEŽEL 2012: 518). Ve skutečnosti se jednalo o příspěvek švédského lingvisty Alvara Ellegårda.

6) Autor zde srovnává vybrané žánry, především pak uměleckou a vědeckou literaturu, z hlediska statistické analýzy vybraných komponentů. Ellegård kupříkladu zjištuje, že v umělecké literatuře desetkrát více převládá minulý čas, než je tomu v odborných textech, což vysvětluje jako přirozenou vlastnost uměleckých narativů vyprávět minulé děje: „The popular novels are narrative, and the narrator typically writes about matters that are supposed to have happened. Hence he has to use the typical narrative tense, which in English is the past. Conversely, the scientific writer classifies states and processes, and draws general conclusions. Hence his use of the present tense. The writers hardly have any choice: their subject matter imposes a choice on them“ (ELLEGÅRD 1982: 521). Tento a další příklady ukazují možné nástrahy, jež vyplývají z př́liš paušalizující aplikace kvantitativních metod. Zejména tvrzení v poslední citované větě se vzhledem k uměleckým narativům jeví jako problematické. 
V Doleželově stanovisku lze rozeznat dvě základní tendence jeho teoretického myšlení. První je snaha zachovat dědictví strukturalismu spolu s jeho úsilím po exaktní metodologii, druhou úsilí soustředit se na kvality sémantické, které v konečném důsledku nelze redukovat na pouhý matematický přepočet. Sémantické kvality jsou sice závislé na formálních strukturních činitelích, ale ne všechny lze úspěšně kvantifikovat. Problematika umělecké sémantiky - zůstaneme-li pouze na poli literárního textu, jeho vlastní struktury, aniž bychom v tuto chvíli uvažovali širší kontextové rámce nebo komunikační strategie, do kterých dílo vstupuje - je komplexní problematikou vyplývající z kombinace funkčně různorodých komponentů díla, $\mathrm{z}$ nichž mnohé se vymykají jednoznačnému empirickému uchopení. To se týká např́ílad narativních pásem, zejména těch, u kterých nelze přesně identifikovat jejich hranice, ale také kategorií, jakými jsou čas, prostor nebo různé axiologické soustavy, které se realizují v rámci fikčních světů a jejichž platnost může být vzhledem k rozsahu fikčního světa celoplošná nebo různě omezená. $V$ takto složitém předivu vztahů může snadno dojít $\mathrm{k}$ hrubému zkreslení výsledků založených pouze na empirické metodě.

$\mathrm{Na}$ straně druhé je kvantitativní příznak určité měřitelné jednotky v rámci strukturního kontextu vždy výrazem strukturním. Nelze totiž přehlížet skutečnost, že kupř́ikladu pouhá frekvence jednotky v daném systému není věcí nahodilou, ale systémovou. Kvantitativní příznak empiricky signalizuje situaci daného prvku v strukturním systému, tj. reflektuje také vliv těch oblastí, které jsou bezprostřední kvantifikaci nepřístupné a jež jsou činiteli vyšších strukturních řad či segmentů. ${ }^{7}$ Důležité je si uvědomovat, že statistický ukazatel tuto situaci nevysvětluje, ale signalizuje. Jeho interpretační síla je matematická, nikoli v našem případě stricto sensu literárněvědná. Proto také Doležel upozorňuje na nezbytnou potřebu kvalitativní interpretace kvantitativních výsledků, která musí být realizována v kontextu příslušné disciplíny: „There are, in principle two possibilities of interpreting numerical data: in terms of qualitative properties and in terms of quantitative structures. [...] In a qualitative interpretation, the data are taken as INDICATORS (indices, symptoms), i.e. their values (or difference in values) are interpreted as signaling the presence of certain qualitative (formal) properties, relations or taxonomies" (DOLEŽEL 1982: 543). ${ }^{8}$

7) Srov: „[F]rekvence slova je inherentní vlastností každého lexému, a do ní se zrcadlí více dalších aspektü“ (ČERMÁK 2010: 244).

8) Druhý přístup ke statistickým hodnotám je podmíněn tím, „if quantitative text characteristics are not interpreted as indicators, but rather as signifying the presence of an autonomous STATISTICAL STRUCTURE of texts" (DOLEŽEL 1982: 545). 
V české literární vědě 2. poloviny 20. století se s výjimkou versologie kvantitativní přístupy přiliš neuplatňují. Avšak i v tomto období můžeme najít velice pozoruhodné úvahy, které se uvedené problematice teoreticky i prakticky věnují. Jedná se o práce Pavla Vašáka, který význam statistiky pro literární vědu demonstroval při řešení textologické problematiky (viz VAŠÁK 1980: 54n). Podobně jako Doležel si také Vašák uvědomuje možnosti a meze kvantitativních metod v literární vědě. Přesto anebo právě proto je schopen jasně a kriticky formulovat, $\mathrm{v}$ čem spočívá základní vztah mezi matematikou a literární vědou: „Chceme-li však použivat matematické metody, je nutno dodržet několik zásad:

1. vycházet $\mathrm{z}$ jasně definovaných výchozích pojmů, bezesporných z hlediska vědy, ve které se matematický přístup uplatňuje; v tom je i výhoda matematických metod, nebot přímo vyžadují jasnou a přesnou definici sledovaného jevu; odlišují problémy věcné od terminologických;

2. výsledky nelze interpretovat matematicky, ale naopak v rámci vědy, ve které se matematický přístup uplatňuje; v případě literární vědy je nutno matematickým výsledkům dát interpretaci literárněvědnou.

Pokud jde o vztah matematiky a literární vědy (jazykovědy a dalších společenskovědních disciplín) vůbec, nedomnívám se, že v budoucnu vznikne nějaká matematická literární věda, obdoba např. existující matematické fyziky, biometriky apod., nakonec i v těchto oborech je nutno výsledkům matematickým dát přislušnou interpretaci fyzikální, biologickou apod., podobně ani existující obor matematická lingvistika není odvětvím matematiky, ale lingvistiky. Je též zřejmé, že nelze mechanicky ztotožňovat matematický za exaktní, nebot’ každá metoda je natolik exaktní, jak exaktní jsou její východiska a proces vysuzování důsledků a poznatků" (VAŠÁK 1980: 51). ${ }^{9}$

Aktuální situace v oblasti aplikace empirických metod v humanitních vědách, včetně literární vědy, je dnes přirozeně ovlivněna možnostmi moderních elektronických korpusů. ${ }^{10}$ Výhody takovýchto nástrojů formální analýzy pro literárněvědnou praxi spočívají především ve třech základních kritériích. Vedle vcelku samozřejmé možnosti objemné excerpce literárních textů se jedná především o schopnost jejich víceúrovňové segmentace pomocí metajazykových kritérií, přičemž definice každého ze segmentu je de facto věcí badatelského rozhodnutí. Definovat jednotlivé vrstvy korpusu lze jak na úrovni textu, kdy lze vyme-

9) K uvedené problematice se Vašák vyjadřuje rovněž ve studii Matematika, exaktnost a literatura, která vyšla samostatně v roce 1986 .

10) Již v 80. letech si Vašák uvědomuje prospěšnost autorských frekvenčních či konkordančních slovníků pro literární vědu: „Literární vědě by nesporně velice pomohlo sestavení nejrůznějších konkordančních a frekvenčních slovníků pro významné autory, literární školy, směry, období, generace apod.“ (VAŠÁK 1980: 52). 
zit různé textové jednotky (slova, věty, odstavce, promluvové segmenty, narativní a deskriptivní segmenty apod.), tak paratextu (autor, doba vzniku, žánr, poetika apod.). Dalším důležitým aspektem se pak stává kvantifikace těchto

segmentů, která ve výsledku směřuje k vytvoření statistických modelů. A právě modelování na bázi kvantitativních kritérií je třetím a nejdůležitějším segmentem kvantitativních metod, které se dnes využívají nejen v lingvistice, ale také v literární vědě. ${ }^{11}$ Jak lze využívat potenciál rozměrných literárních korpusů, nám aktuálně ukazuje zejména zahraniční výzkum. ${ }^{12}$ Zde pouze jmenujeme základní možnosti, které lze teoreticky očekávat od korpusově-kvantitativních metod v literární vědě.

Statistické modely mohou mapovat žánrové pole určitých vývojových etap národních literatur. Výrazný impulz dnes vidíme např́klad v práci Franca Morettiho (viz MORETTI 2014). Dalším důležitým aspektem je výzkum v oblasti tematiky, kdy se nabízí různé kvantitativní metody tematické analýzy. Hlavní podněty dnes vychází ze stylometrie; výzkumu jsou podrobovány i dílčí textové segmenty, zejména narativní nebo dialogické části textu. Zajímavé výsledky může přinést experimentování, ${ }^{13}$ které by spočívalo v kombinacích textových a paratextových kritérií. Konkrétně lze takto uvažovat vztahy mezi tematikou, žánrem, poetikou a časovou disperzí sledovaného jevu. Další oblast empirického výzkumu se může zaměřit na vztah mezi literárním kánonem a literárním korpusem a sledovat, jak se na pozadí literárního korpusu realizují jednotlivé strategie kánonu.

V uvedených souvislostech je ovšem důležité znovu zopakovat, že teprve vzájemné propojení obou základních metodologických modů (kvantitativního a kvalitativního) umožní adekvátní využití empirických metod v literární vědě. Statistické modely jsou de facto objektivní manifestací strukturních

11) Na význam modelování v literární vědě u nás v minulosti upozornil Eduard Petrů (viz PETRŮ 1968: 72n).

12) Jedná se o zahraniční univerzitní pracoviště, jakými jsou především Stanford Literary Lab (https://litlab.stanford. edu/) nebo Nebrasca Literary Lab (http://litlab.unl.edu/) a další. Obě univerzitní pracoviště jsou zaměřena na kvantitativní a korpusové vytěžování zejména narativních uměleckých textů. Poznatky, které badatelé těchto pracovišt prezentovali, at již formou dílčích studií, které jsou volně přístupné na webových stránkách Stanford Literary Lab (https://litlab.stanford.edu/pamphlets/), anebo nejnověji v monografii Canon/Archive: Studies in Quantitative Formalism From the Stanford Literary Lab (2017), reprezentují aktuální tendenci v tomto typu výzkumu. Jedná se především o stylometrické metody, tzv. analýzu hlavních komponentů (Principal Component Analysis) nebo dendrogramy, ale rovněž o metodologické postupy, se kterými pracuje tzv. literární kartografie využívající GIS systémů pro mapování fikční topografie. V českém prostředí je třeba jmenovat projekt Korpusu českého verše (http://versologie.cz/v2/web_content/corpus.php?lang=cz), který umožňuje kvantitativní výzkum české poezie 19. a počátku 20. století z hlediska statistického vyhodnocování základních versologických kategorií, jakými jsou metrum, rým či eufonie.

13) O experimentu v literární vědě v souvislosti s využitím exaktních metod u nás pojednával Eduard Petrů (viz PETRŮ 1968). 
charakteristik sledovaných jevů a procesů. Přesto se výsledná interpretace nesmí omezit na popisování těchto modelů. Jejím úkolem se musí stát schopnost propojit výsledky empirické analýzy s teoretickými rámci a východisky literární vědy jakožto autonomní disciplíny. Jinými slovy, empirické metody jsou vždy podřízeny potřebám literární vědy a nikoli naopak. ${ }^{14}$ Pouze tak se empirické modely mohou stát smysluplnou součástí takové literárněvědné praxe, která je schopna využít exaktní metody v rámci vlastní teorie a souboru otázek, a nikoli samoúčelnou součástí literárněvědných studií, které by se na jejich základě pouze snažily vzbudit zdání exaktnosti.

\section{LITERATURA}

ČERMÁK, František

2010 Lexikon a sémantika (Praha: Nakladatelství Lidové noviny)

\section{DOLEŽEL, Lubomír}

1965 „Pražská škola a statistická teorie básnického jazyka“, Česká literatura 13, č. 2, s. 110-113

1969 „A Framework for the Statistical Analysis of Syle“, in Statistic and Style (New York: American Elsevier Publishing Company), s. 10-25

1982 „A Note on Quantification in Text Theory. Discussion of Alvar Ellegård’s Paper ,Genre Styles, Individual Styles, and Autorship Identification", in Text Processing. Text Analysis and Generation. Text Typology and Attribution. Proceedings of Nobel Symposoim 51 (Stockholm: Almqvist \& Wiksell International), s. 539-552 2012 „Doslov překladatele“, in Možné světy v humanitních vědách, v umění a v přírodních vědách (Praha: Academia), s. 518-520

\section{ELLEGÅRD, Alvar}

1982 „Genre Styles, Individual Styles, and Autorship Identification“, in Text Processing. Text Analysis and Generation. Text Typology and Attribution. Proceedings of Nobel Symposoim 51 (Stockholm: Almqvist \& Wiksell International), s. 519-537

KLIVAR, Mojmír

1984 „Význam kvantitativní lingvistiky pro literární teorii“, in Literárněvědný sborník Památníku národního písemnictví (Praha: PNP), s. 24-52

\section{LEVÝ, Jiří}

1971 Bude literární věda exaktní vědou? (Praha: Československý spisovatel)

PETRŮ, Eduard

1968 Exaktní metody v literárněvědné práci (Olomouc: Univerzita Palackého v Olomouci)

14) Je třeba rovněž dodat, že př́itomnost těchto metod nepodmiňuje existenci literární vědy jakožto humanitní vědecké disciplíny. 
PLECHÁČ, Petr

Korpus českého verše (http://versologie.cz/v2/web_content/corpus.php?lang=cz)

MORETTI, Franco

2017 Canon/Archive: Studies in Quantitative Formalism From the Stanford Literary Lab (New York: n+1 Foundation)

2014 Grafy, mapy, stromy. Abstraktní modely literární historie (Praha: Karolinum)

TĚŠITELOVÁ, Marie

1974 Otázky lexikální statistiky (Praha: Academia)

1987 Kvantitivní lingvistika (Praha: Státní pedagogické nakladatelství)

VAŠÁK, Pavel

1980 Metody určování autorství (Praha: Academia)

1986 Matematika, exaktnost a literatura (Praha: Československý spisovatel)

WELLEK, René

1999 Teorie literatury (Olomouc: Votobia)

Mgr. Richard Změlík, Ph.D., richard.zmelik@upol.cz, Katedra bohemistiky, Filozofická fakulta Univerzity Palackého v Olomouci, Česká republika / Department of Czech Studies, Faculty of Arts, Palacký University Olomouc, Czech Republic 